\title{
6 CORRESPONDENCE
}

Hospital crises

P V Scott, FFARCS.............. 1071

Which prophylactic drugs for malaria?

J R Copper, MRCP.............. 1071

Polio immunisation and travel

N A Ward, MB................. 1072

Measles and vaccine protection

S R Preblud, MD . . . . . . . . . . . . . . . . . . 1072

Smallpox vaccination

J N Ormrod, fRCS............. 1072

Smallpox vaccination in the Forces

D P B Pound, MRCGP . . . . . . . . . . . . . . . 1072

Are breast-fed babies still getting a raw deal in hospital?

Patricia J Bailey-Smith... . . . . . . . . . . . 1072

Infant feeding practices: a cause for concern

D L J Freed, MD, and Deirdre Mackay,

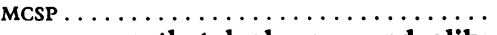

Drug names that look or sound alike

R A Fairburn, MB; C Romer, MB . . . . . 1073

Diazepam for distressing procedures

A W Fowler, FRCS................ 1073

Personality and breast cancer

D Loshak.................... 1073

\section{Congenital varicella}

Major I Alexander, MRCOG. . . . . . . . . . 1074

The premature breech

M St C Hopper, MRCOG.

Antenatal prediction of sex

I A Hughes, FRCP(C), and K M Laurence,

FRCPATH $\ldots \ldots \ldots \ldots \ldots \ldots \ldots \ldots \ldots \ldots$

Beta-blocker withdrawal syndrome
C T Dollery, FRCP, and T J B Maling,

Crace

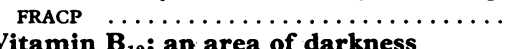

Vitamin $B_{12}$ : an area of darkness

D M Matthews, FRCPATH, and J C Linnell,

PHD . . . . . . . . . . 1075

Life-threatening arrhythmias and

intravenous cimetidine

E N S Fry, FFARCS... . . . . . . . . . . 1075

Day-bed units

C A C Clyne, FRCs, and C W Jamieson,

FRCS; Deborah P Moncrieff, MB.........

Smoking and acclimatisation to altitude

D C Snashall, MRCP............. 1075

Wanted: a new wound dressing

L E Hughes, FRCS and others; R Forrest;

J Watson, FRCs ................ 1075

Complication of acupuncture

J Tuke, MB .................. 1076
Serum thyroglobulin in differentiated

thyroid cancer

I D Hay, MRCP, and C A Gorman, FACP 1076

Revised consultant contract

A N G Clark, FRCP ; P J Adams, FRCOG, and

others; J A R Anderson, MRCP......... 1076

Medical academics and research

workers

J P Payne, fFarcs. . . . . . . . . . . . . . . 1077

Private practice for pathologists

M H Hughes, FRCPATH.............. 1077

The Three Wise Men

F C Shelley, fFarcs............ 1077

The forgotten men

W H Bond, Frcs. . . . . . . . . . . . 1078

Clinical practice and community

medicine

J A Murie, Frcs

First things first

T T Irvin, FRCSED. .

Lack of flexibility in vocational

training?

D P Brown, MB...

If I was forced to cut

R I Button, MB............... 1078

We may return unduly long letters to the author for shortening so that we can offer readers as wide a selection as possible. We receive so many letters each week that we have to omit some of them. Letters must be signed personally by all their authors. We cannot acknowledge their receipt unless a stamped addressed envelope or an international reply coupon is enclosed.

\section{Hospital crises}

SIR,-Our hospital faces yet another ongoing crisis situation. Regular readers will recall last year's contretemps, when, in the regretted absence of circuit diagrams, we attempted the recommended DHSS test for electrical safety ( $500 \mathrm{~V}$ is applied to instruments designed for use at $240 \mathrm{~V}) .^{1}$ Our electrician is much better since finding a job in industry; but, as might have been foreseen, the authorities have abolished the need for circuit diagrams by the laughably simple expedient of providing no money for new hospital equipment.

Last year we asked the district for items of medical and surgical equipment amounting to $£ 100000$ plus depreciation. We received $£ 25000$. This year we need $£ 250000$. We have received-nothing. The increasing demand arose partly through the effluxion of time and partly through an influx of new, young consultants hot from the centres of excellence with strange ideas about raising standards, no financial provision for their arrival having been made by the employing authority.

We have tried to solve the perennial dilemma by asking the district management team to set aside $3 \%$ of its annual budget for replacing unsafe or worn-out equipment and for buying novel instruments of proved quality relevant to our work as a bread-andbutter hospital (we did not ask for jam). The district management team, to its eternal credit, has done so. Unfortunately, it soon became apparent that the district was seriously in the red. (This is known as "cost limits.") Our $3 \%$ will now be absorbed in recouping some of the 1978-9 deficit. Meanwhile we are short of equipment worth $£ 250000$, of which, at a modest estimate, probably a good three- quarters really is necessary. At the same time, in the absence of square deal RAWP, we continue to overspend revenue at the rate of some thousands of pounds a week. (People in our district have an irritating and non-costeffective habit of getting ill; that, and their inborn craving for medicine, is really one of the most serious difficulties with which we have to contend.)

The solution to which we were inescapably driven was to seek help from our League of Friends. We hated to do this. We see it as wrong to ask the Friends to provide money which will eventually be used by doctors and nurses to treat patients: that was, and is, the statutory obligation laid on the National Health Service in 1948. However, our need was clamant. We had to compromise our beliefs in what we saw to be the best shortterm interests of our patients. In the long term, of course, we have created an unforgiving precedent.

If we are now to assume that the bulk of the hospital service is to be financed from flag days, an interesting philosophical point arises. What happens, let us say, if the League of Friends decides to raise capital for a scanner for computed tomography (CT)? What if, after superhuman efforts by many decent people, a CT-scanner is duly provided? Who then is to pay for the running costs? Embarrassed health authorities, no doubt, will in due course pass on their embarrassment to the Department of Health and to the Secretary of State. In the meantime, if the equipment is not to gather dust, management teams will have been forced into changing their priorities, or acting in some other way which is likely to be to the detriment of patients.
If you spend a capital sum, whether it comes from the coffers of an impoverished Health Service or from raffle tickets, there will always be a revenue consequence, however small. To find that extra revenue on a fixed budget with little or no development money is almost an impossibility; the patient is bound to lose out somewhere along the line. That is something for our colleagues up and down the country to ponder as they strive to offer twentieth century medicine at the nineteenth century prices which the public has already paid. Give us the tools, and we will finish the job.

Department of Anaesthetics,

Bromsgrove, Worcs

' Scott, P V, British Medical fournal, 1978, 2, 632.

\section{Which prophylactic drugs for malaria?}

SIR,-The continuing trickle of letters in your columns concerning imported tropical diseases underlines the growing awareness of the importance of this subject. Rightly, chief interest centres on the control of malaria, with emphasis on the importance of publicising the need to take prophylactic drugs. However, while debate continues on the best way of ensuring that the public understands the need to take drugs for the correct period, relatively little thought seems to have been given to the question of which drug to take.

Authorities recommend, in general, that the most appropriate antimalarial drugs for most areas are pyrimethamine and proguanil. It is always dangerous to rely on others' anecdotes 